\title{
THE EFFECT OF Sn-DOPING ON OPTICAL, ELECTRICAL AND MORPHOLOGICAL PROPERTIES OF SPRAY-PYROLYSED ZnO FILMS
}

\author{
Andrey Escala Alves ${ }^{1 *}$ \& Herval Ramos Paes Jr. ${ }^{1}$
}

\begin{abstract}
RESUMO
ALVES, A. E.; PAES JR., H. R. The effect of Sn-doping on optical, electrical and morphological properties of spray-pyrolysed $\mathrm{ZnO}$ films. Perspectivas Online: Exatas \& Engenharia, v. 10, n. 29, p. 1-12, 2020.

O presente trabalho investigou os efeitos da dopagem com estanho nas propriedades morfológicas e óptico-elétricas dos filmes de óxido de zinco produzidos pela técnica de spray-pirólise. Os filmes exibiram marcas de impacto de gotículas ao longo da superfície. Micrografias de topo revelaram partículas em contraste preto de sais não-decompostos após a dopagem com estanho. Esses aspectos morfológicos não comprometeram o desempenho óptico, embora possam ter contribuído para o aumento da resistividade elétrica devido ao efeito de espalhamento de carga na superfície. A condutividade elétrica foi

dopagem com estanho aumentou. Os íons de estanho ocuparam regiões intersticiais da matriz hospedeira, atuando como defeitos convencionais. A transmitância ótica dos filmes em $550 \mathrm{~nm}$ não foi significativamente afetada pela dopagem com estanho, mas uma leve perda de transmitância foi observada após adição de $1 \%$ at. Sn. Estreitamento da banda proibida foi observado após dopagem com estanho. $\mathrm{O}$ valor da banda proibida reduziu de 3,25 eV, referente ao filme intrínseco, para 3,16 eV e 3,23 eV, após dopagem com $1 \%$ at. $\mathrm{Sn}$ e $2 \%$ at. Sn, respectivamente.
\end{abstract} reduzida à medida que a concentração de

Palavras-chave: Óxidos condutores transparentes; Filmes de $\mathrm{ZnO}$; Dopagem com Sn; Spray-pirólise.

\footnotetext{
${ }^{1}$ Northern Fluminense State University Darcy Ribeiro -- UENF - Advanced Materials Laboratory - LAMAV/CCT - Av. Alberto Lamego, 2000, Parque Califórnia, Campos dos Goytacazes, RJ, Postal code: 28013-602, Brazil.

(*) e-mail: andreyea@gmail.com
} 


\title{
O EFEITO DA DOPAGEM COM Sn SOBRE AS PROPRIEDADES ÓPTICAS, ELÉTRICAS E MORFOLÓGICAS DE FILMES DE ZnO PRODUZIDOS PELA TÉCNICA DE SPRAY-PIRÓLISE
}

\author{
Andrey Escala Alves ${ }^{1 *}$ \& Herval Ramos Paes Jr. ${ }^{1}$
}

\begin{abstract}
ALVES, A. E.; PAES JR., H. R. O efeito da dopagem com Sn sobre as propriedades ópticas, elétricas e morfológicas de filmes de $\mathrm{ZnO}$ produzidos pela técnica de spray-pirólise. Perspectivas Online: Exatas \& Engenharia, v. 10, n. 29, p. 1-12, 2020.

The present work has investigated the effects of tin doping on morphological and optical-electrical properties of zinc oxide films produced by spray-pyrolysis technique. The films exhibited droplet impact marks along the surface. Top-view micrographs disclosed black clusters of non-decomposed salts after tin doing. These morphological aspects have not compromised optical performance although they may have contributed to the rise in electrical resistivity due to charge scattering on the surface. Electrical

conductivity was lowered as tin-doping concentration increased. Tin ions occupied interstitial sites in the host matrix and acted as conventional defects. The film transmittance at $550 \mathrm{~nm}$ was not significantly affected by tin doping, yet a slight loss in transparency was observed after 1 at. $\%$ Sn doping. Bandgap narrowing was observed after tin doping. Bandgap values decreased from $3.25 \mathrm{eV}$, for the intrinsic films, to $3.16 \mathrm{eV}$ and 3.23 $\mathrm{eV}$ for tin doping levels of 1 at. $\% \mathrm{Sn}$ and 2 at. $\% \mathrm{Sn}$, respectively
\end{abstract}

Keywords: Transparent conductive oxide; $\mathrm{ZnO}$ film; Sn-doping; Spray-pyrolysis;

\footnotetext{
${ }^{1}$ Universidade Estadual do Norte Fluminense Darcy Ribeiro - UENF - Laboratório de Materiais Avançados - LAMAV/CCT Av. Alberto Lamego, 2000, Parque Califórnia, Campos dos Goytacazes, RJ, CEP: 28013-602, Brasil.

(*) e-mail: andreyea@gmail.com 


\section{INTRODUCTION}

In the last decades, there has been a great advance in the optical-electronic industry in the development of innovative devices such as smartphones, flexible HD screens, smart windows, as well as solar cells. An important component of these devices is transparent conductive oxides (TCO). TCOs are semiconductor materials that have both low electrical resistivity and high optical transmittance in the visible region of the light spectrum. Numerically, a good TCO film has electrical resistivity of about $10^{-4} \Omega \mathrm{cm}$ and transmittance greater than $85 \%$ (LEWIS and PAINE, 2000). Tin-doped indium oxide $\left(\operatorname{In}_{2} \mathrm{O}_{3}: \mathrm{Sn}\right)$ is one of the most used TCO in the industry (KUMAR and ZHOU, 2010). However, low abundance of In in earth's crust, high market price, chemical instability have increased the number of researches in search of possible substitutes (MINAMI, 2008; BLAKE et al., 2008; KUMAR and ZHOU, 2010; DIAS, 2005; DIAS and PAES JR., 2006; SANCHEZ, 2014; LICURGO, 2018).

Zinc oxide films have emerged as an alternative due to their high thermal and chemical stability, great abundance in earth's crust and their easy and economical manufacturing process (FORTUNATO et al., 2007; YAROSHEVSKY, 2006). Zinc oxide films are naturally n-type semiconductors, which means that they have higher concentration of negative charge carriers in the crystal structure as a consequence of some lattice defects. However, those defects do not contribute efficiently to carrier mobility at low temperature, being the reason why they are insulators at room temperature (FORTUNATO et al., 2007).

A way to improve electrical conductivity is by doping zinc oxide films with elements from groups IIIA and IVA, e.g. Al, Ga, Sn, Ge, in order to increase the number of negative carriers (BEDIA et al., 2017). Regarding tin doping, two free negative carries are added into the structure for each $\mathrm{Sn}^{4+}$ when they occupy $\mathrm{Zn}^{2+}$ vacancies (BOUGRINE et al., 2005). Commonly, the electrical properties are optimised with Sn doping; however, the contrary is observed when the dopant are placed in interstitial sites, becoming conventional defects (ACHARYA et al., 2012; AJILI et al., 2013).

It has been reported (BEDIA et al., 2015) that Sn incorporation can increase optical transmission of $\mathrm{ZnO}$ films doping with up to $2 \% \mathrm{Sn}$. On the other hand, Ajili et al. (2013) observed a reduction in transmission to $55-65 \%$ with increase of Sn content. Tin doping also decreases optical bandgap. The broadening and narrowing of optical bandgap occur due to the excess of carrier concentration (CHAHMAT et al., 2014; AJILI et al., 2013; BEDIA et al., 2017).

Therefore, more investigations of tin doping effects on the properties of zinc oxide films should be conducted. For this purpose, this work aims to analyse the morphological, electrical and optical changes to zinc oxide films produced by spray-pyrolysis technique at different Sn concentration levels.

\section{EXPERIMENTAL PROCEDURES}

Sn-doped zinc oxide films with different Sn concentrations (0, 1 and 2 at. \%) were produced by automatic spray-pyrolysis technique. More details of the spray-pyrolysis system operation are reported elsewhere (ROCHA, 2017). A $0.05 \mathrm{M}$ aqueous zinc acetate [ $\mathrm{Zn}$

Persp. Online: exatas \& eng., Campos dos Goytacazes, 29 (10) 1 - 12 - 2020

https://ojs3.perspectivasonline.com.br/ 
$\left.\left(\mathrm{CH}_{2} \mathrm{CO}_{2}\right)_{2}\right]$ solution was prepared by mixing zinc acetate dihydrate $\left[\mathrm{Zn}\left(\mathrm{CH}_{2} \mathrm{CO}_{2}\right)_{2} \cdot 2 \mathrm{H}_{2} \mathrm{O}\right]$ (Sigma-Aldrich, $\geq 98 \%$ purity) into a mixture of deionised water and isopropyl alcohol P.A. (Isofar, 99.5\%) (3:1). A 0.05M dopant solution was obtained by dissolving tin (II) chloride dihydrate $\left[\mathrm{SnCl}_{2} \cdot 2 \mathrm{H}_{2} \mathrm{O}\right.$ ] (Sigma-Aldrich, $\geq 98 \%$ purity) into deionised water which was later poured into the zinc acetate solution to achieve the dopant concentration desired. Droplets of acetic acid (Sigma-Aldrich, $\geq 99.7 \%$ purity) were added to improve solution clarity. The films were spray-pyrolysed onto microscopic slides of clear glass produced by Bioslide which were cleaned in boiling water for $30 \mathrm{~min}$ followed by 15 -min ultrasonic cleaning. The spraypyrolysis conditions are shown in Table 1 in detail.

Table 1: Deposition Parameters of intrinsic and tin-doped zinc oxide films.

\begin{tabular}{rc}
\hline Deposition Parameters & \\
\hline Flow rate $(\mathrm{mL} / \mathrm{min})$ & 0.5 \\
Solution Concentration $(\mathrm{M})$ & 0.05 \\
Deposition time $(\mathrm{min})$ & 30 \\
Substrate Temperature $\left({ }^{\circ} \mathrm{C}\right)$ & 450 \\
Carrier gas & Compressed Filtered Air \\
Carrier gas pressure $\left(\mathrm{Kgf} / \mathrm{cm}^{2}\right)$ & 0.5 \\
Distance between nozzle and substrate & 30 \\
$(\mathrm{~cm})$ & 20 \\
Nozzle movement along X-axis $(\mathrm{mm})$ & 20 \\
Substrate movement along y-axis (mm) & 0,1 and $2 \%$ \\
{$[\mathrm{Sn}]($ at. $\%)$} & \\
\hline
\end{tabular}

The surface morphology was examined by confocal microscopy. This technique was also used to determine the film thickness as an average of five width measurements from cross-section micrographs as shown in Figure 1.

Electrical conductivity behaviour was investigated in a temperature range of 200 to $350{ }^{\circ} \mathrm{C}$. For this purpose, the films were coupled to a probe with two copper tips connected to an Agilent 3458A digital multimeter with high input impedance, in resistance function. The set was inserted in a chamber containing a stainless-steel plate, connected to a thermocouple type K, which sends the temperature information to the controller. Silver glue was used to connect the tips of the system and the film. More details can be found in (ROCHA, 2017). The activation energy was calculated by Arrhenius equation (Eq. 1), where Ea is the activation energy, $\mathrm{k}$ is Boltzmann constant, $\mathrm{T}$ is the temperature in Kelvin, $\sigma_{\mathrm{o}}$ is a preexponential factor and $\sigma$ is the electrical conductivity.

$$
\sigma=\sigma_{o} e^{-\frac{E a}{k T}}
$$

Persp. Online: exatas \& eng., Campos dos Goytacazes, 29 (10) 1 - 12 - 2020 
The optical transmittance measurements were carried out with SPEKORD model M500 UV-VIS spectrophotometer. The absorption coefficient ( $\alpha$ ) was calculated from (Eq. 2), where $\mathrm{T}_{\mathrm{R}}$ is the optical transmittance at a certain wavelength and $w$ is the film thickness. Tauc plots were used to determine the optical bandgap of the tin doped zinc oxide films produced as previously described by ROY et al. (2018).

$$
\alpha=\frac{-\ln \left(T_{R}\right)}{w}
$$

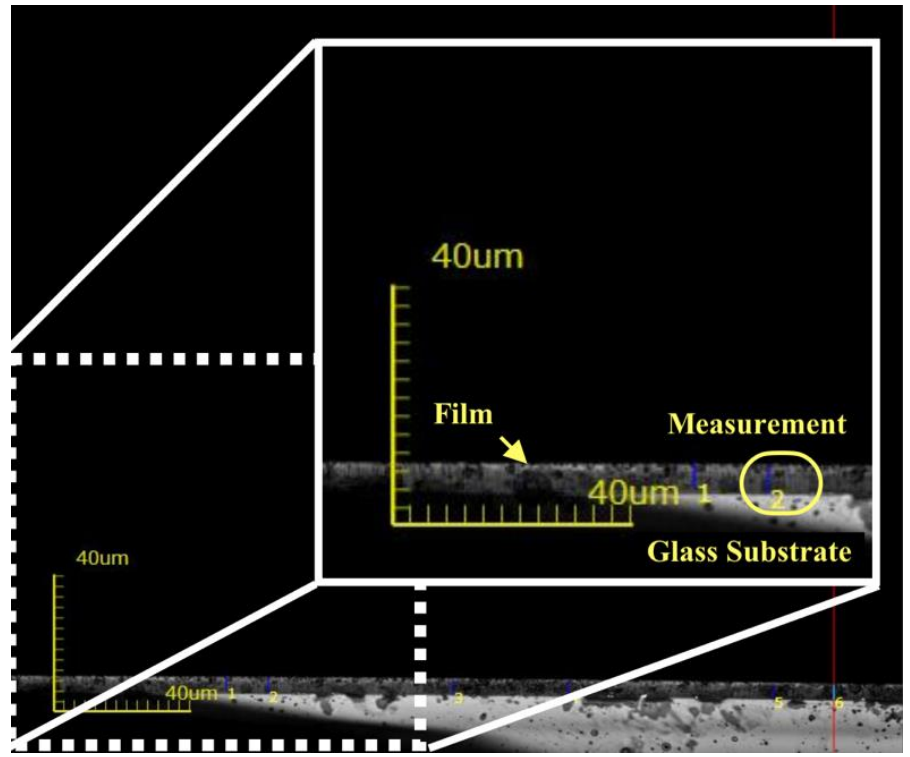

Figure 1: Thickness measurements of the films produced using confocal microscopy.

\section{RESULTS AND DISCUSSION}

\subsection{Effect of Sn-doping on Morphological Properties}

Figure 2 shows a top-view image from the surface morphology of the $\mathrm{Sn}$-doped $\mathrm{ZnO}$ films obtained by confocal microscopy. All specimen showed droplet impact marks. These marks were circular and exhibited a white/grey contrast on the surface of the intrinsic films.

Small black clusters of dry particles were observed on the surface of Sn-doped $\mathrm{ZnO}$ films. Although it is not possible to identify the nature of these particles by optical microscopy, they may correspond to non-decomposed salts which could have been formed prior reaching the hot substrate. No tin-derived secondary phase formation has been reported in previous works up to 10 at. \% level, thus further analysis on structure should be conducted (ACHARYA et al., 2012; CHAMAT et al., 2014). A surface having less droplet marks and better background uniformity was achieved when doping zinc oxide films with 2 at. \% Sn.

Persp. Online: exatas \& eng., Campos dos Goytacazes, 29 (10) $1-12-2020$ https://ojs3.perspectivasonline.com.br/ 

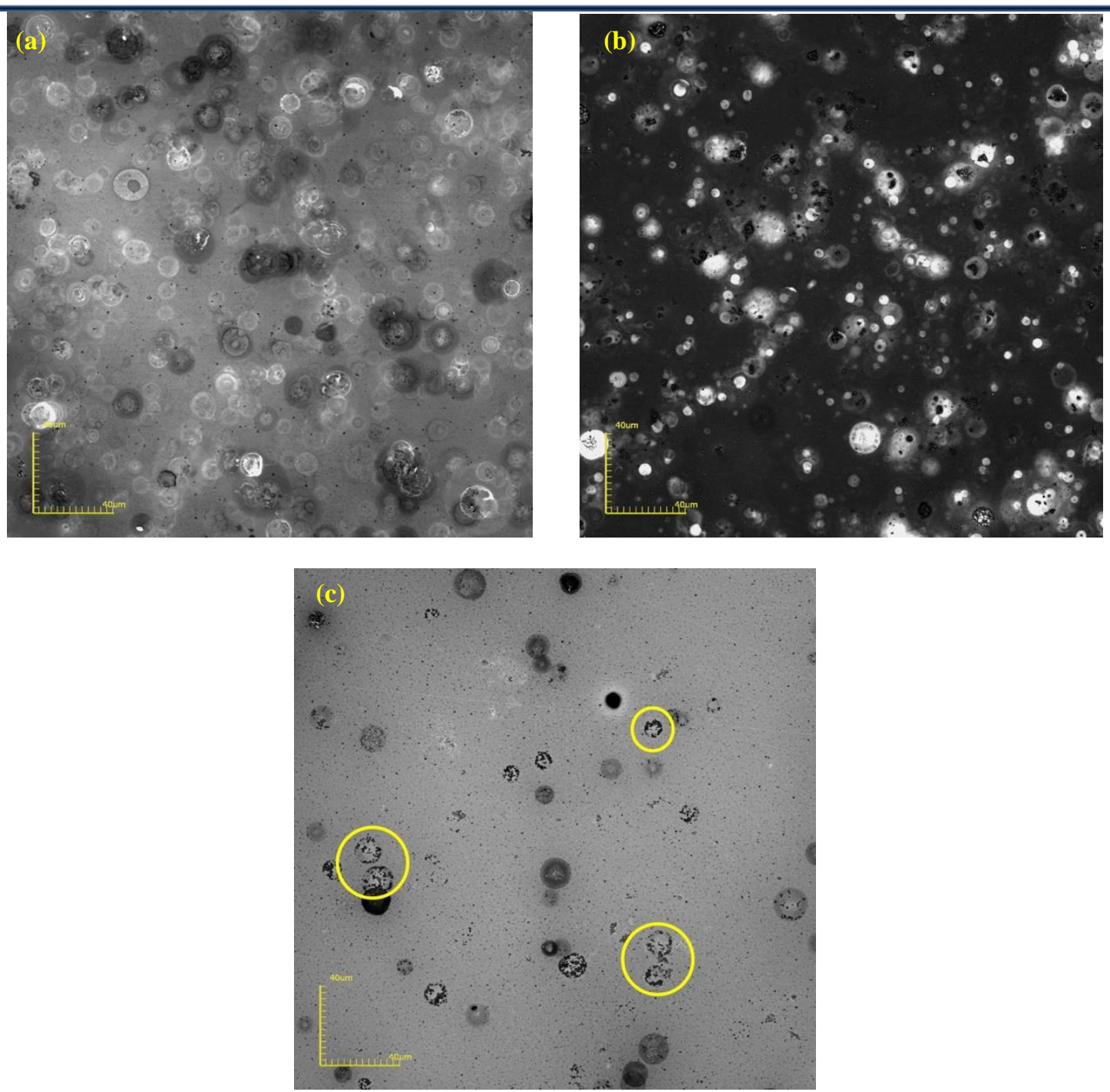

Figure 2: Top-view confocal micrograph taken at 1075x from the surface of $\mathrm{ZnO}$ films doped with Sn at different concentrations: (a) intrinsic, 0; (b) 1 and (c) 2 at. \% Sn. The yellow circles highlight the presence of black clusters of non-decomposed salts.

\subsection{Effect of Sn-doping on Electrical Properties}

The electrical conductivity behaviour with increasing measuring temperature is shown in Figure 3. As expected for semiconducting films, the electrical resistivity dropped as temperature increased. However, tin doping has strongly decreased the electrical conductivity of the spray-pyrolysed $\mathrm{ZnO}$ films compared to the intrinsic ones, especially when tin concentration was 2 at. \%. This indicate $\mathrm{Sn}^{4+}$ ions may have occupied interstitial sites in the crystal lattice, acting as common defects, instead of positioning at $\mathrm{Zn}^{2+}$ sites; however, other sort of defects in the crystal structure can reduce electrical conductivity, such as grain boundaries in polycrystal films (KASAP et al., 2017). When doping elements occupy interstitial sites, they lose their ability to boost electron carrier concentration and become conventional defects, being ineffective as dopant impurities (BOUGRINE et al., 2005).

Persp. Online: exatas \& eng., Campos dos Goytacazes, 29 (10) 1 - 12 - 2020

https://ojs3.perspectivasonline.com.br/ 


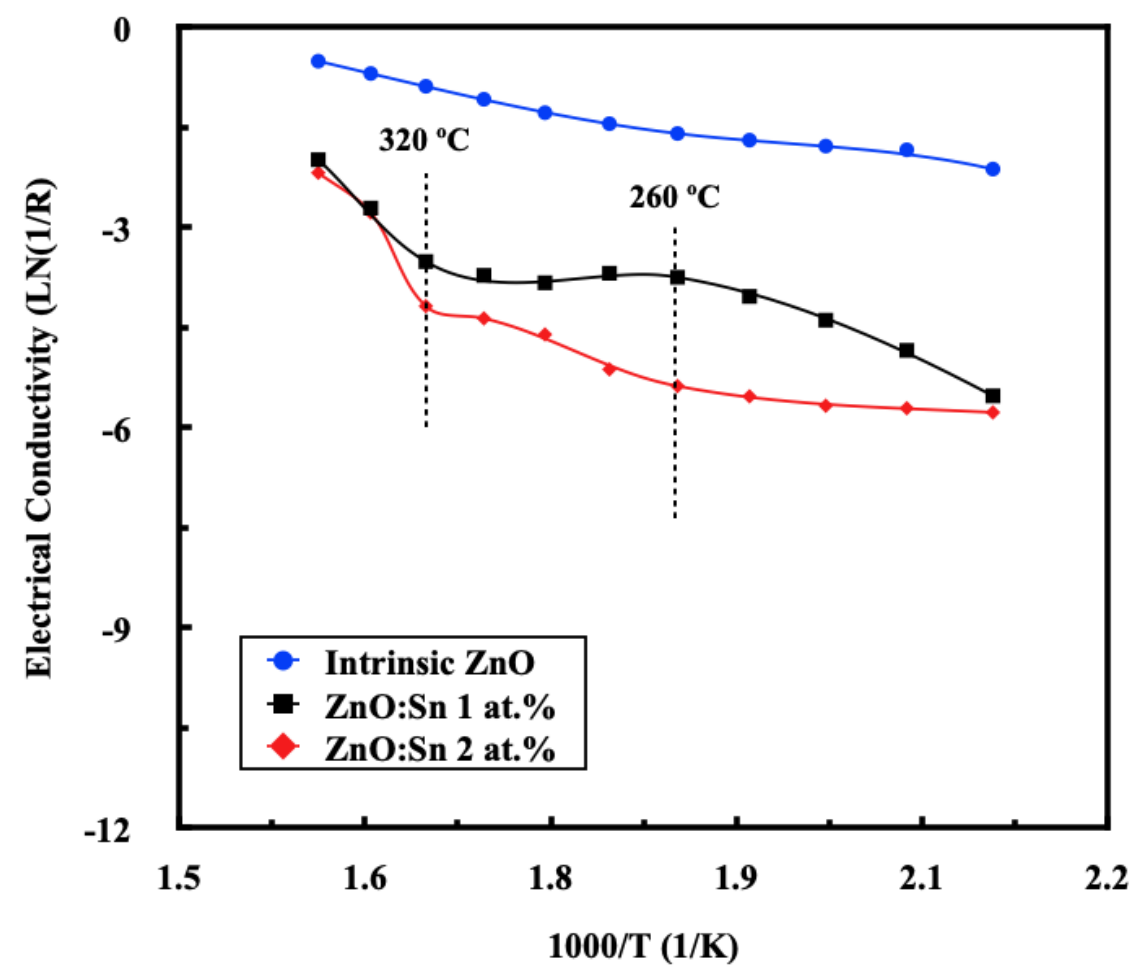

Figure 3: Electrical conductivity behaviour with inverse measuring temperature of intrinsic and tin doped $\mathrm{ZnO}$ films.

Shifts in the curve slope characterises changes to the electrical conducting behaviour and they could be seen in Figure 3 for Sn-doped $\mathrm{ZnO}$ films. Electrical conductivity is poor below $260^{\circ} \mathrm{C}$ suggesting that few tin ions were ionised. At this temperature range, dopant impurities do not effectively contribute to carrier concentration and end up acting as conventional defects which create deep states in the bandgap leading where carrier transportation is slow.

A transition region, between 260 and $320^{\circ} \mathrm{C}$, where conductivity is not much affected by temperature change, is as a result of two competing process: thermal excitation of negative carries and oxygen adsorption, as previously reported by Acharya et al. (2012).

At temperatures above $320^{\circ} \mathrm{C}$, more dopant impurities are ionized and able to occupy substitutional sites in the host matrix, raising negative carrier concentration. Accordingly, carrier transport by thermal excitation of electrons into the conduction band is dominant at high temperatures. Even though an increase in electrical conductivity was observed at high temperatures, overall electrical conductivity of the tin doped zinc oxide films was smaller compared to intrinsic films.

The activation energies for electrical conductivity at low and high temperatures of intrinsic and tin doped $\mathrm{ZnO}$ films are shown in Table 2. The values were greater than the ones previously reporter by Prajapati et al. (2013) for both low and high temperature range. 
Table 2: Activation energy of $\mathrm{ZnO}$ films varying $\mathrm{Sn}$ concentration.

\begin{tabular}{ccc}
\hline $\begin{array}{c}\text { Sn Doping } \\
(\text { at. \%) }\end{array}$ & \multicolumn{3}{c}{$\begin{array}{c}\text { Activation Energy } \\
(\mathbf{e V})\end{array}$} \\
\hline $\mathbf{0}$ & & 0.26 \\
& $\underline{\text { Low Temperature }}$ & High Temperature \\
$\mathbf{1}$ & 0.64 & 1.62 \\
$\mathbf{2}$ & 0.14 & 2.13 \\
\hline
\end{tabular}

A feasible solution for improving electrical conductivity in tin doped $\mathrm{ZnO}$ films is ensuring the dopant ions will occupy substitutional sites in the crystal lattice. This may be achieved by performing heat treatment under a reducing atmosphere after the deposition process (PAES JR. et al., 1989; DIAS and PAES, JR., 2006).

\subsection{Effect of Sn-doping on Optical Properties}

Although the morphology of $\mathrm{Sn}$ doped $\mathrm{ZnO}$ films was less uniform than the intrinsic specimen, the superficial defects did not strongly compromise the optical properties of the films. It has been previously reported that $\mathrm{Sn}$ doping may reduce the optical transmittance at $550 \mathrm{~nm}$ (AJILI et al 2013). This was true for tin doped films with 1 at. \%. However, the increase to 2 at. \% improved the film optical transmittance to a value close to the intrinsic film, as shown in Figure 4.

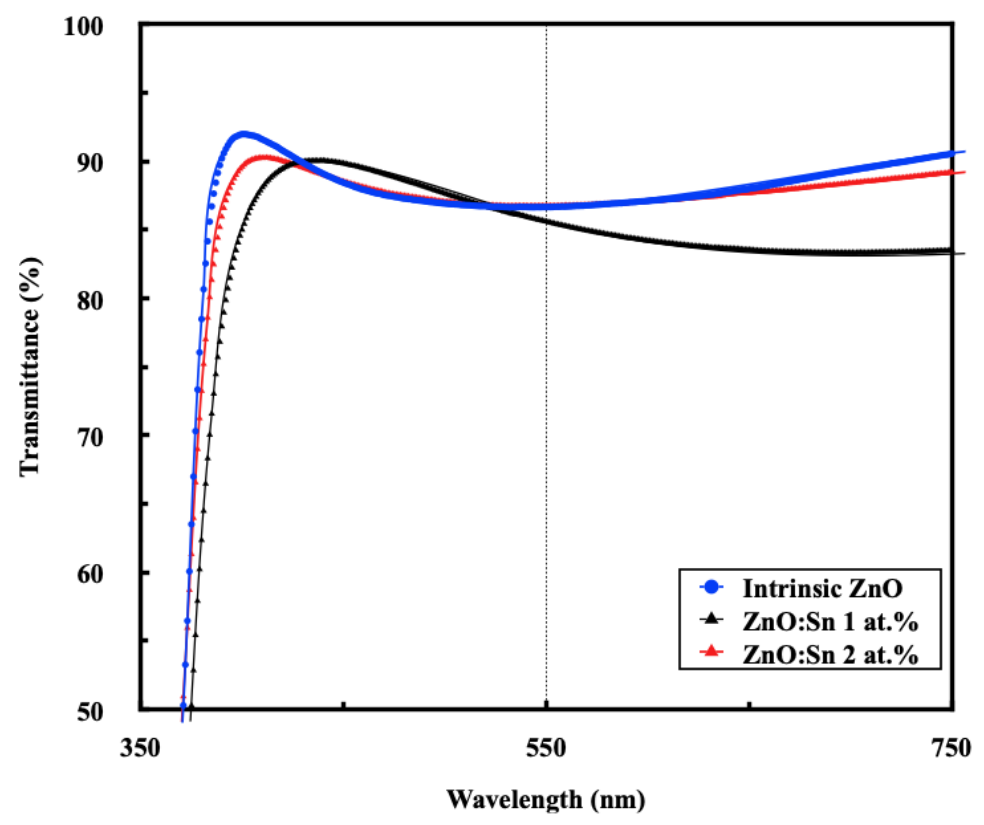

Figure 4: Optical transmittance of intrinsic and tin doped zinc oxide films.

The Tauc plot was used to determine the optical bandgap for each sample and is shown in Figure 4. The bandgap was $3.25 \mathrm{eV}$ of intrinsic zinc oxide films as previously reported (ROY et al., 2018). Tin doping caused the absorption edge to shift to lower $(h v)$ 
values. This phenomenon indicates that $\mathrm{Sn}^{+4}$ ions introduced deep states into the bandgap, and it corroborates to the lower conductivity observed in tin doped films. Conductivity from deep donors occur by hooping transport as opposed to conventional band transport where free electrons are excited from the valance band to the conduction band (ACHARYA et al. 2012; MANOHARAN et al. 2015). The narrowing and widening of optical bandgap are competing effects which have been previously reported in Sn-doped $\mathrm{ZnO}$ films (CHAHMAT et al., 2014; MANOHARAN et al., 2015).

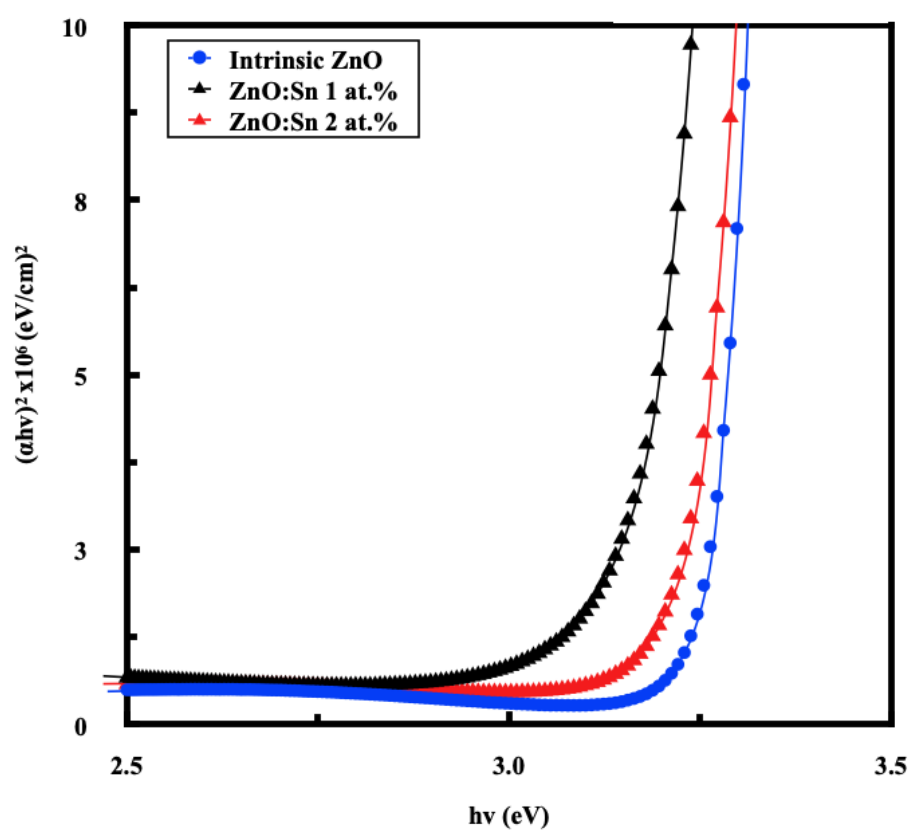

Figure 4: $(\alpha h v)^{2}$ versus $(h v)$, Tauc plot, for intrinsic and tin doped zinc oxide films.

Table 3 summarises the optical properties of the undoped $\mathrm{ZnO}$ films and the $\mathrm{Sn}$-doped $\mathrm{ZnO}$ films at different $\mathrm{Sn}$ concentration as well as the film thicknesses. The absorption coefficient at $550 \mathrm{~nm}\left(\alpha_{550}\right)$ increased after Sn doping, even though no significant reduction in transmittance was observed. The morphological defects may have also contributed to the apparent increase of the absorption coefficient once these defects can reflect the incident beam.

Table 3. Thickness and Optical Properties of $\mathrm{ZnO}$ films doped with different $\mathrm{Sn}$ concentration.

\begin{tabular}{ccccc}
\hline $\begin{array}{c}\text { Sn doping } \\
(\% \text { at. })\end{array}$ & $\begin{array}{c}\text { Thickness } \\
(\boldsymbol{\mu m})\end{array}$ & $\begin{array}{c}\mathbf{T}_{\mathbf{5 5 0}} \\
(\boldsymbol{\%})\end{array}$ & $\begin{array}{c}\boldsymbol{\alpha}_{550} \\
\left(\mathbf{x 1 0}^{\mathbf{2}} \mathbf{c m}^{-1}\right)\end{array}$ & $\begin{array}{c}\mathbf{E}_{\mathbf{g}} \\
(\mathbf{e V})\end{array}$ \\
\hline $\mathbf{0}$ & $4.96 \pm 0.32$ & 86.65 & 2.89 & 3.25 \\
$\mathbf{1}$ & $3.96 \pm 0.27$ & 85.60 & 3.93 & 3.16 \\
$\mathbf{2}$ & $4.54 \pm 0.32$ & 86.74 & 3.13 & 3.23 \\
\hline
\end{tabular}




\section{CONCLUSIONS}

The incorporation of $\mathrm{Sn}$ as dopant element into spray-pyrolysed $\mathrm{ZnO}$ films was evaluated according its effects on morphological, electrical and optical properties.

The confocal microscopy revealed droplet solution marks on the film surface for all films produced. Black clusters of particles were observed on the surface of tin-doped films only. Less droplet marks and better background uniformity was found in tin doped oxide films with 2 at. \%. Tin doping has reduced the electrical conductivity of zinc oxide films with increasing doping content. This suggests that tin ions may not have occupied substitutional positions in the crystal lattice. As a result, deep states in the bandgap created and hopping transport, a slower mechanism for carrier transport, is activated. Optical transmittance was not strongly affected by the morphological defects seen on the surface of the films. Tin doping narrowed the bandgap for spray-pyrolysed zinc oxide films and increased the absorption coefficient those films at $550 \mathrm{~nm}$.

Overall, tin doping up to 2 at. $\%$ is not recommend for improving the optical and electrical properties of as-prepared zinc oxide films produced by automatic spray-pyrolysis deposition system.

\section{ACKNOWLEDGEMENTS}

This study was financed in part by the Coordenação de Aperfeiçoamento de Pessoal de Nível Superior - Brasil (CAPES) - Finance Code 001 and CNPq - Conselho Nacional de Desenvolvimento Científico e Tecnológico.

\section{REFERENCES}

ACHARYA, A. D.; MOGHE, S.; PANDA, R.; SHRIVASTAVA, S. B.; GANGRADE, M.; SHRIPATHI, T.; PHASE, D. M.; GANESAN, V. Growth and characterization of nanostructured Sn doped ZnO. Journal of Molecular Structure, v. 1022, p. 8-15, 2012.

AJILI, M.; CASTAGNÉ, M.; TURKI, N. K. Study on the doping effect of Sn-doped ZnO thin films. Superlattices and Microstructures, v. 53, p. 213-222, 2013.

BEDIA, A.; BEDIA, F. Z.; AILLERIE, M.; MALOUFI, N. Structural, electrical and optical properties of Al-Sn codoped $\mathrm{ZnO}$ transparent conducting layer deposited by spray pyrolysis technique. Superlattices and Microstructures, v. 111, p. 714-721, 2017.

BEDIA, F. Z.; BEIDA, A.; AILLERIE, M.; MALOUFI, N.; BENYOUCEF, B. Structural, optical and electrical properties of Sn-doped zinc oxide transparent films interesting for organic solar cells (OSCs). Energy Procedia, v. 74, p. 539-546, 2015.

BLAKE, P.; BRIMICOMBRE, P. D.; NAIR, R. R.; BOOTH, T. J.; JIANG, D.; SCHEDIN, F.; PONOMARENKO, L. A.; MOROZOV, S. V.; GLEESON, H. F.; HILL, E. W.; GEIM, A. K.; NOVOSELOV, K. S. Graphene-based Liquid Crystal Device. Nano Letters, v. 8, n. 6, p. 1704-1708, 2008.

BOUGRINE, A.; ADDOU, M.; KACHOUANE, A.; BÉRNÈDE, J.C.; MORSLI, M. Effect of tin incorporation on physicochemical properties of $\mathrm{ZnO}$ films prepared by spray pyrolysis. Materials Chemistry and Physics, v. 91, p. 247-252, 2005.

Persp. Online: exatas \& eng., Campos dos Goytacazes, 29 (10) 1 - 12 - 2020

https://ojs3.perspectivasonline.com.br/ 
CHAHMAT, N.; SOUIER, T.; MOKRI, A.; BOUOUDINA, M.; AIDA, M. S.; GHERS, M. Structure, microstructure and optical properties of Sn-doped $\mathrm{ZnO}$ thin films. Journal of Alloys and Compounds, v. 593, p. 148-153, 2014.

DIAS, C. A. C. M. Produção e caracterização de filmes finos de óxido de zinco intrínsecos e dopados com alumíno e boro. Campos dos Goytacazes: [s.n.], 2005. Dissertação de mestrado. PPGECM/UENF.

DIAS, C. A. C. M.; PAES JR., H. R. Produção e Caracterização de Filmes Finos de Óxido de Zinco Intrínsecos e Dopados com Alumínio e Boro. Revista Matéria, v. 11, p. 267-272, 2006.

FORTUNATO, E.; GINLEY, D.; HOSONO, H.; PAINE, D. C. Transparent Conducting Oxides for Photovoltaics. MRS Bulletin, v. 32, p. 242-247, 2007.

KASAP, S.; KOUGHIA, C.; RUDA, H. E. Electrical Conduction in Metals and Semiconductors. In: Springer Handbook of Electronic and Photonic Materials. Springer International Publishing, p. 19-44, 2017.

KUMAR, A.; ZHOU, C. The race to replace tin-doped indium oxide: Which material will win? ACS Nano, v. 4, n. 1, p. 11-14, 2010.

LEWIS, B. G.; PAINE, D. C. Applications and processing of transparent conducting oxides. MRS Bulletin, p. 22-27, 2000.

LICURGO, J. L. C. Propriedades morfológicas, estruturais, elétricas e óticas de filmes de óxido de zinco dopados com cobre depositados por spray-pirólise. Campos dos Goytacazes: [s.n.], 2018. Dissertação de mestrado. PPGECM/UENF.

MANOHARAN, C.; PAVITHRA, G.; DHANAPANDIAN, S.; DHAMODARAN, P.; SHANTHI, B. Properties of spray pyrolised ZnO:Sn thin films and their antibacterial activity. Spectrochimica Acta Part A: Molecular and Biomolecular Spectroscopy, v. 141, p. 292299, 2015.

MINAMI, T. Present status of transparent conducting oxide thin-film development for indium-tin-oxide substitutes. Thin Solid Films, p. 5822-5828, 2008.

PAES JR., H. R.; PINHO, L. M. C. O.; LOSCH, W. H. P. Filmes finos de óxido de zinco produzidos por spray-pirólise. IV Congresso da Sociedade Brasileira de Microeletrônica, Anais do IV CSBME, Porto Alegre-RS, p. 393-402, 1989.

PRAJAPATI, C. S.; KUSHWAHA, A.; SAHAY, P. P. Optoelectronics and formaldehyde sensing properties of tin-doped $\mathrm{ZnO}$ thin films. Applied Physics A: Materials Science and Processing. Springer. 2013.

ROCHA, O. P. Implementação de um Sistema de Spray-Pirólise Automatizado para Deposição de Filmes Cerâmicos com Gradiente de Funcionalidade e Dispositivos Multicamadas. Campos dos Goytacazes: [s.n.], 2017. Tese de doutorado. PPGECM/UENF.

Persp. Online: exatas \& eng., Campos dos Goytacazes, 29 (10) 1 - 12 - 2020 https://ojs3.perspectivasonline.com.br/ 
ROY, D.; SAMU, G. F.; HOSSAINA, M. K.; JANÁKY, C.; RAJESHWARA, K. On the measured optical bandgap values of inorganic oxide semiconductors for solar fuels generation. Catalysis Today, v. 300, p. 136-144, 2018.

SANCHEZ, S. A. I. Preparação e caracterização de filmes de ZnO para utilização como sensores de gás. Campos dos Goytacazes: [s.n.], 2014. Dissertação de mestrado. PPGECM/UENF.

YAROSHEVSKY, A. A. Abundances of chemical elements in the Earth's crust. Geochemistry International, v. 44, n. 1, p. 44-55, 2006. 